\title{
KAPLICE ŚW. KAZIMIERZA I NIEPOKALANEGO POCZECCIA NAJŚWIĘTSZEJ MARYI PANNY PRZY KATEDRZE WILEŃSKIEJ OCZAMI KARMELITANEK BOSYCH - NIEROZPOZNANE ŹRÓDLO Z 1638 ROKU
}

I6 listopada I638 r. cztery mniszki: przeorysza Eufrazja od św. Jacka (Teodora Piaseczyńska, zm. I648), Angelika od Najświętszego Sakramentu (Elżbieta Filipowicz, zm. I663), Maria Magdalena od Zbawiciela (Anna Żaboklicka, zm. I677) oraz Anna od św. Bartłomieja (Anna Łęcka, zm. I677) ${ }^{1}$ wyruszyły z klasztoru św. Józefa w Lublinie do Wilna², gdzie miały objąć nową placówkę fundowaną przez podkanclerzego wielkiego litewskiego Stefana Paca (I587-I640) i jego żonę Annę Marię Ancillę z Rudominów Dusiackich (zm. I643)³. Trasa podróży, towarzyszące jej wydarzenia, niebezpieczne przeprawy ${ }^{4}$, a także spostrzeżenia na temat ówczesnego świata, w tym zupełnie dla karmelitanek bosych odmiennego - litewskiego 5 , znane są dzięki dość dokładnemu dziennikowi Opisanie początków fundacjej wilińskiej [!]

\footnotetext{
Zastąpiła s. Annę od św. Bartłomieja (Zuzanna Włodarz, ur. 1597), która podczas podróży z Krakowa do Lublina zachorowała i wkrótce zmarła (28 XI). Kronika klasztoru Karmelitanek Bosych pw. św. Józefa w Lublinie, oprac. Cz. Gil, Poznań 2012, s. 77-78; idem, Karmelitanki bose w Polsce, Kraków 2011, s. 42. Błędne informacje na temat Włodarzówny oraz związków zakonnic z krakowskim lub lubelskim konwentem podaje K. Targosz, Piórem zakonnicy. Kronikarki w Polsce XVII w. o swoich zakonach i swoich czasach, Kraków 2002, s. 90-91.

2 Pierwsze dwie zakonnice były profeskami klasztoru św. Marcina w Krakowie, kolejne pochodziły z konwentu lubelskiego. Cz. Gil, Stownik polskich karmelitanek bosych 1612-1914, Kraków 1999, s. 22-25, 60-61, 65; idem, Karmelitanki bose..., op. cit., s. 41.

3 Na temat tej fundacji oraz działalności na niwie artystycznych inicjatyw Stefana Paca zob. A.S. Czyż, Fundacje artystyczne rodziny Paców: Stefana, Krzysztofa Zygmunta i Mikołaja Stefana Paców. „Lilium bonae spei ab antiquitate consecratum", Warszawa 2016, s. 38-154.

4 Tuż za Bielskiem Podlaskim, skąd wyruszono „22 Novembra, w poniedziałek w dzień świętej Cecyliej [...] był za miastem most, przez który było trzeba jachać, był zły i wjazd nań przykry, niebezpieczna przeprawa bardzo" (Archiwum Karmelitanek Bosych w Krakowie na Wesołej - dalej jako AKB - AKB 255, k. 53r). Za Sokółką „26 Novembra, w piątek rano przede dniem wstaliśmy w drogę się wybierać, wiatr był przykry i mroźny i mróz dobry. Zawiał drogę śniegiem wiatr, dlategośmy też błądzili” (AKB 255, k. 56r). Cytaty z dziennika opracowano według zasad transkrypcji źródeł historycznych do połowy wieku XVIII w wersji B. Zachowano jednak formy językowe charakterystyczne dla autorki, w tym konsekwentne stosowanie przymiotnika „wiliński” miast „wileński”. Wszelkie wtrącenia i rozwinięcia skrótów zaznaczono przez nawias kwadratowy.

5 W okolicach Labna 26 XI „kazali nam patrzyć WW. OO. [tj. karmelici bosi z Wilna] podniozszy trochę wela na chleb wielki Borys [...]. Acz powiadali, że to jeszcze nie prawdziwy Borys, bo jeszcze nie tak czarny jako on bywa” (AKB 255, k. 56v). Dzień później w gospodzie „kwasu też także przysłali kosztować, który po tym chlebie Borysie popijają, bo go nie mogą połknąć, aż popijać tym kwasem” (AKB 255, k. 58r). Język litewski zakonnice skomentowały: „bardzo niezrozumiała ich mowa, kiedy nam [przypadkiem spotkana dziewczyna w Serejach 29 XI] powiadała, jako u nich co zowią". AKB 255, k. 61v.
} 
karmelitanek bosych pod tytułem Ś[w]. O[jca] N[aszego] Józefa R[oku] P[ańskiego] I638. Dnia I8 Grudnia, który sporządziła s. Maria Magdalena od Zbawiciela ${ }^{6}$.

Zakonnica prowadziła diariusz na bieżąco od I4 listopada I638 r., kiedy podkanclerz wielki litewski zjawił się wraz z żoną w Lublinie ${ }^{7}$, do 2I grudnia, kiedy zakończyły się uroczystości introdukcji zakonnic do klasztoru wileńskiego. Dziennik podlegał jeszcze redakcji, bowiem autorka powracała do spraw, które zdarzyły się już po wyjeździe zakonnic z Lublina ${ }^{8}$. Ostateczna wersja kroniki została wpisana w I727 r. przez kopistkę s. Cecylię Teresę od Ofiarowania Najświętszej Maryi Panny (Anna Petronela Zacherla) do Księgi fundacji klasztorów karmelitanek bosych prowincjej polskiej Ducha Św[iętego] od Roku Pańskiego I6I2 przechowywanej w klasztorze św. Teresy od Jezusa i św. Jana od Krzyża w Krakowie na Wesołej. Diariusz zajmuje w nim karty od 46 recto do 90 verso9.

$\mathrm{Na}$ kolejnych stronach dziennika s. Maria Magdalena od Zbawiciela nie tylko wymieniła miejscowości, przez które zakonnice przejeżdżały (m.in. Lubartów, Czemierniki, Wohyń, Piszczec, Bielsk Podlaski, Choroszcz, Białystok, Sokółka, Labno, Lejpuny, Sereje, Preny, Troki), ale także zapisała informacje, które wydały się karmelitankom bosym ważne. Dotyczyły one m.in. kościołów, w których mniszki miały okazję uczestniczyć we mszy świętej. Była to sposobność na bardzo krótkie opisanie świątyni czy też jej wyposażenia ${ }^{10}$. Tak było w Czemiernikach, gdzie karmelitanki bose stanęły I7 listopada. Po mszy świętej modliły się jeszcze przed ołtarzem Najświętszej Maryi Panny, w którym „piękny ten obraz jest, tam trochę pobywszy, opiece się Królowej Naszej oddawszy poszliśmy do karety" "I. Z kolei o kościele w Białymstoku (24 XI) s. Maria Magdalena od Zbawiciela wypowiedziała się następująco: „kościół piękny, murowany”’2. Nieco więcej miejsca kronikarka poświęciła farze

\footnotetext{
6 Autorkę dziennika zidentyfikowała Karolina Targosz (K. Targosz, op. cit., s. 91). Badaczka opublikowała także niewielkie fragmenty dziennika oraz bardzo krótko omówiła przebieg podróży karmelitanek bosych. Nie ustrzegła się przy tym błędów w odczytaniu nazw miejscowości (K. Targosz, op. cit., s. 91: Horoszcz - zamiast Choroszcz, Prępy zamiast Preny). Dla porządku należy zauważyć, że z właściwym zapisaniem nazw miejscowości miała problem sama kronikarka oraz kopista tekstu (zob. AKB 255, k. 50r). Przed Karoliną Targosz skromne fragmenty dziennika, bardzo swobodnie odczytanego, opublikował Rafał Kalinowski w pierwszym tomie opracowania Klasztory karmelitanek bosych w Polsce, na Litwie i Rusi. Ich początek, rozwój i tułactwo w czasie rozruchów wojennych w XVII w. Rzecz osnuta na kronikach klasztornych, Kraków 1900.

Pacowie towarzyszyli zakonnicom w podróży przed dwa dni, a później dołączyli do nich w Prenach.

8 Omawiając przygotowania do wyjazdu, o wspomnianej zakonnicy z Krakowa - s. Annie od św. Bartłomieja, pod datą 14 XI 1638 r., kronikarka napisała ,jednak że z woli Boskiej [...] rozchorowała się w tej drodze i prędko zeszła z tego świata." AKB 255, k. 46v.

9 Inna wersja dziennika pod nieco zmienionym tytułem (Historia fundaciej klasztoru nasze[go] wileńskie[go] ś[w]. Józepha przez Jaśnie Wielm [ożnego] J[ego] M[ości] Pana Stephana Paca podkanclerzego W[ielkiego] X[ięstwa] L[itewskiego] i matżonkę je [go] Maria Ancillę Rudominównę Dusiacka Pacowa fundowanego roku pański[ego] 1638) została umieszczona na ostatnich kartach Krótkiej kroniki fundacji karmelitanek bosych klasztoru św. Józepha Wilnie, która stanęła roku 163818 Decembra. Księga ta, pochodząca z archiwum klasztoru karmelitanek bosych w Wilnie, jest przechowywana w Archiwum Krakowskiej Prowincji Zakonu Karmelitów Bosych w Krakowie (sygn. AKBW 22). Dziennik s. Marii Magdaleny od Zbawiciela zajmuje w niej strony 333-362 i został przepisany przez dwie kopistki. Obie wersje: z Archiwum Karmelitanek Bosych w Krakowie na Wesołej oraz z Archiwum Krakowskiej Prowincji Zakonu Karmelitów Bosych zostały przez autorkę artykułu porównane. Choć zauważono drobne nieścisłości, nie wpływają one na prezentowane treści. Dotychczasowi badacze dziennika s. Marii Magdaleny od Zbawiciela: Rafał Kalinowski i Karolina Targosz nie znali egzemplarza z Archiwum Krakowskiej Prowincji Zakonu Karmelitów Bosych.

10 W kościołach słuchano mszy świętej stosunkowo rzadko. Najczęściej towarzyszący karmelitankom bosym zakonnicy z klasztoru św. Teresy w Wilnie odprawiali je we dworach, w których nocowano.

11 AKB 255, k. 48v.

12 AKB 255, k. 54r.
} 
w Trokach, słynnemu litewskiemu sanktuarium, gdzie zakonnice wraz z fundatorami stanęły I6 grudnia: „kościół murowany piękny, w wielkim ołtarzu jest obraz Panny Najświętszej. Wotów bardzo wiele wisi w ołtarzu, i w stronę ołtarza. Ten obraz Panny Najświętszej Mariej jest piękny i cudowny. Tak tam z rozmaitych miejsc ludzie się zjeżdżają, w rozmaitych potrzebach swoich, jako i w Częstochowy, i wielkie łaski otrzymywaną od Najświętszej Panny. [...] Prowadzili nas Ich M[o]ść [Pacowie] do kościoła, jakośmy przyszli przed obraz Panny Przenajśw[iętszej] odsłoniono obraz"’3. Do świątyni zakonnice udały się także dzień później na poranną mszę świętą ,było nie widno, i złe wchodzenie do kościoła górą, a ślisko było,

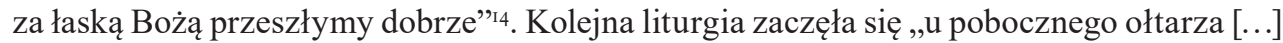
śpiewano i na organach grano"15.

Zasób określeń s. Marii Magdaleny od Zbawiciela ${ }^{16}$, których używała do opisania widzianych budowli i ich wyposażenia jest bardzo ubogi. Więcej interesowały ją okoliczności sprawowanych mszy świętych: relikwie i cudowne obrazy ${ }^{17}$, uczestnicy liturgii ${ }^{18}$ i oprawa muzyczna $^{19}$ oraz miejsce, jakie zakonnice zajmowały w przestrzeni kościoła ${ }^{20}$. Fakt ten nie powinien dziwić, nie tylko dlatego że autorką dziennika była karmelitanka bosa niezainteresowana blichtrem świata zewnętrznego. Zasób określeń, którymi w pierwszej połowie siedemnastego stulecia dokonywano opisu i interpretacji dzieł sztuki, był w Rzeczpospolitej bardzo skromny ${ }^{21}$. Mimo tego usprawiedliwiającego stwierdzenia polszczyznę karmelitanki bosej należy określić jako dość prostą, choć dziennikowi nie można odebrać autentycznego zaangażowania i radości, jaki niósł ze sobą fakt podróży do nowej placówki. Co za tym idzie,

13 AKB 255, k. 79v.

14 AKB 255, k. 81r. Na marginesie dodajmy, że wspomniany kościół znajduje się na dość stromym wzniesieniu i także dziś podejście do niego, szczególnie zimą, może stanowić problem.

15 AKB, k. 81r.

16 Anna Żaboklicka była córką sędziego sochaczewskiego Andrzeja i Barbary z Radomieckich. W wieku 25 lat, 11 IV 1633 r. w Lublinie, złożyła śluby zakonne. Po pobycie w Wilnie, gdzie pełniła funkcję podprzeoryszy, 11 V 1645 r. powróciła do macierzystego konwentu. 26 I 1648 r. wybrano ją kalwarią. Na przełomie 1648 i 1649 wraz z innymi zakonnicami przebywała w Budzisławiu na Kujawach. 11 V 1649 r. udała się na drugą fundację w Lublinie, obejmując funkcję podprzeoryszy. Następnie, w latach 1661-1664, była tam przeoryszą. 11 X 1665 r. wyjechała wraz z dwiema siostrami na placówkę do Poznania, gdzie w latach 1668-1674 pełniła funkcję przeoryszy. Kierowała wówczas pracami przy budowie kościoła i klasztoru. Jej twórczość literacka, prócz omawianego tu dziennika, obejmuje cenny życiorys s. Teresy Barbary od Najświętszego Sakramentu, czyli Teofili z Kretkowskich Zadzikowej (wydany przez Czesława Gila w 2013 r. w serii „Źródła Karmelitańskie”). S. Maria Magdalena od Zbawiciela była także uznaną kopistą oraz inicjatorką przepisywania znacznej części kodeksu ascetycznego, powstałego w klasztorze poznańskim. Kronika klasztoru..., op. cit., s. 77; Cz. Gil, Słownik polskich..., op. cit., s. 60-61; idem, Karmelitanki bose..., op. cit., s. 42, 78-79.

17 W kościele pw. św. Teresy w Wilnie, wówczas jeszcze drewnianym, zakonnica odnotowała (17 XII), ,relikwia Ś[w]. M[atki] N[aszej św. Teresy] stała na ołtarzu oprawna, na kształt monstranciej”. AKB 255, k. 81v.

18 W Białymstoku 24 XI „słuchaliśmy dwóch mszy św. i komunikowaliśmy, J[ej] M[ość] pani marszałkowa [Aleksandra Marianna Wiesiołowska, krewna podkanclerzyny litewskiej] była też na tych mszach w kościele.” AKB 255, k. 54r.

19 W świątyni w Prenach - starostwie dzierżonym przez podkanclerzego litewskiego - 12 XII ,śpiewacy [...] naszego Jego M[o]ści [Stefana Paca] bardzo porządnie i pięknie grali i śpiewali.” AKB 255, k. 73v.

20 W preneńskim kościele 12 XII mszę sprawowano u pobocznego oltarza, przed tą lawka gdzieśmy klęczały. AKB 255, k. 74 v.

${ }^{21}$ Na ten temat zob. m.in. H. Dziechcińska, Sarmaci wobec sztuki malarskiej. Na przykładzie pamiętników epoki, w: Corona scientiarum. Studia z historii literatury i kultury nowożytnej ofiarowane profesorowi Januszowi Palcowi, red. J.A. Chrościcki, Warszawa 2004, s. 356-359; J. Tazbir, Wrażliwość artystyczna szlachty polskiej, w: Cała historia to dzieje ludzi... Studia z historii spolecznej ofiarowane profesorowi Andrzejowi Wyczańskiemu w 80-ta rocznice urodzin i 55-lecia pracy naukowej, red. C. Kukla, Białystok 2004, s. 55-64. 
diariusz odznacza się swoistym niezaprzeczalnym urokiem, wpisując się w kulturę literacką karmelitanek bosych, które w klasztorach uczyły się nie tylko odbioru słowa pisanego, ale zajmowały się pisarstwem religijnym, w tym autobiografiami mistycznymi i liryką, a także kronikarstwem ${ }^{22}$.

Wiele miejsca w dzienniku s. Marii Magdaleny od Zbawiciela zajął opis uroczystości z I9 grudnia I638 r., związanych z wprowadzeniem mniszek do klasztoru wileńskiego ${ }^{23}$. Do stolicy Wielkiego Księstwa Litewskiego karmelitanki bose wraz z towarzyszącymi im zakonnikami, fundatorami i ich świtą przybyły dwa dni wcześniej. Po ceremonii powitania w drewnianym wówczas kościele pw. św. Teresy odpoczywały w pałacu Paców przy ul. św. Jana. Nazajutrz, I8 grudnia, „W sobotę przed dziesiątą, tak była wola Ich Mościów i W[ielebnych] Ojc[ó]w naszych, żebyśmy jechały z J[ej] M[oś]cią [Anną Marią Ancillą z Rudominów Dusiackich] do kościoła do zamku, kędy św. Kazimierz leży, tam nas prowadzili do tamtej kaplice gdzie leży. Kiedyśmy wchodziły w kościół, J[ego] M[ość] x. kanonik wiliński, stał u drzwi, i każdą z nas kropił. Przyszliśmy do kaplice, gdzie zaraz zaczęła się msza św[ięta] czytana [... $]^{24}$. Wysłuchawszy dwóch mszy, trochę poczekawszy co było ludzi cokolwiek i czeladzi J[ego] M[oś]ci kazano im ustąpić z kaplice, myśmy zostali z J[ej] M[oś] cią. Kazali nam W[ielebni] O[jc]o[wie] odsłonić wela, i patrzyć wszędy. Święty Kazimierz leży w ołtarzu, to jest: pod samym stołem ołtarzowym, i na nim się msza św[ięta] odprawuje. Kędy antepediu[m] ma być, to nie masz, jedno kraty mosiądzowe, a słupy hebanowe z białą kością, sama trumna, w której leży św[ięty] srebrna. Otworzyli W[ielebni] O[jc]o[wie] kratę jedną, tameśmy klęczały trochę oddając się temu św[iętemu] w obronę jego, całowałyśmy trumnę. Ołtarz wszystek ze srebra, i z hebanu, wielki, piękny, i kosztowny. Persony wielkie srebrne i krucyfiks wielki, pod nim Najśw[iętsza] Panna, i św. Jan, zaś po jednej stronie św. Kazimierz, po drugiej św. Zygmunt, wyżej także dwie persony, jeszcze wyżej Panna Przenajśw[iętsza] i dwa aniołowie. Te rzeczy wszystko srebrne. Sama kaplica wszytka marmurowa, wielka i piękna, i kosztem [...] wielkim wystawiona, bardzo wysoka i wesoła, ale jeszcze z wierzchu niedokończona, jeszcze rosztowanie jest. Po jednej stronie jest malowany św. Kazimierz bardzo pięknie i wszytek żywot jego. Po drugiej stronie św. Zygmunt także malowany, wyżej zaś dosyć piękne obrazy są malowane, aleśmy ich przed rusztowaniem nie mogli dojrzeć. Prosiła J[ej] M[o]ść, abyśmy też szły do kaplice, kędy przed tym leżał św. Kazimierz, bo go to do drugiej kaplice przeniesiono. A tę marmurową kaplicę król Jego $\mathrm{M}[0]$ ść św[iętej] pamięci Zygmunt swoim kosztem wystawić kazał a teraźniejszy zaś [Władysław IV] przenieść kazał do tej nowej. A w tej kaplicy, gdzie przed tym św. Kazimierz leżał, leży nieboszczyk J[e]go M[o]ść x. biskup wiliński [Eustachy Wołłowicz], wuj J[ej] M[ość] Dobrodziejki naszej [Anny Marii Ancilli z Rudominów Dusiackich], który bardzo był przychylny naszemu zakonowi, i kiedy się $\mathrm{W}[\mathrm{ielebni}] \mathrm{O}[\mathrm{jc}] \mathrm{o}[$ wie] nasi wprowadzili [do Wilna w I626 r.], on sam mszę św[iętą] śpiewał. Mówiła J[ej] M[ość], że kiedy by był doczekał tego przyjazdu naszego, niezmierną pociechę by był miał z tego. Jakośmy przyszły do tej kaplice prosiła J[ej] M[o]ść, abyśmy za niego po paciorku zmówiły. Po tym kazali się nam odsłonić W[ielebni] O[jc]o[wie] nasi i patrzyć. Piękna kaplica, wesoła, wysoka, obraz Panny

22 H. Popławska, Kultura literacka karmelitanek bosych w Polsce (XVII-XVIII wiek), Gdańsk 2006, s. 10-20, $22-$ $-23,26,40-56$.

23 Zob. A.S. Czyż, op. cit., s. 146-148.

${ }^{24}$ Tu następuje opis spowiedzi zakonnic, odbytej przed przyjazdem do katedry wileńskiej. Jako że nie wnosi on ważnych informacji, został pominięty. 
Przenajśw[iętszej], na ziemi marmurem położona. Zaś szłyśmy do zakrystjej, co przy tej kaplicy, bardzo sposobna i piękna, i na górze takaż, abo jeszcze piękniejsza, tam jakośmy przyszły, mówił do nas oracją ten kanonik co z nami chodził"25.

Wyprawa karmelitanek bosych do katedry została zorganizowana z inicjatywy Paców i tak przeprowadzona, aby z całej świątyni zaprezentować im i towarzyszącej świcie dwie realizacje pośrednio związane z podkanclerstwem litewskim. Stefan Pac nadzorował z ramienia króla budowę i dekorację sanktuarium św. Kazimierza ${ }^{26}$. Najpewniej ten sam zespół artystów od ok. I627 r. pracował przy kaplicy grobowej biskupa Eustachego Wołłowicza ${ }^{27}$, bliskiego krewnego Anny Marii Ancilli z Rudominów Dusiackich, gdzie wcześniej złożone były relikwie królewicza. Twórcy związani z tymi dwiema prestiżowymi realizacjami byli także czynni przy fundacjach Pacowskich ${ }^{28}$.

Nawiedzane miejsca, a szczególnie kaplica św. Kazimierza, wywarły na kronikarce, a z całą pewnością także na pozostałych zakonnicach, ogromne wrażenie. Stąd s. Maria Magdalena od Zbawiciela umieściła w dzienniku dosyć dokładny opis sanktuarium rozpoczynając od scharakteryzowania najważniejszej jego części, czyli ołtarza z relikwiami. Znajdowały się one poniżej mensy, podtrzymywanej przez hebanowe kolumny zdobione aplikacjami z białej kości. Srebrny relikwiarz był widoczny przez podwójną mosiężną kratę, która była otwierana dla znaczniejszych gości. Powyżej mensy znajdowała się konstrukcja nastawy ołtarzowej wykonana z hebanu i ze srebra. Zakonnica określiła ją mianem wielka, a kolejne dane potwierdzają, że była to struktura trójosiowa i dwukondygnacyjna ze zwieńczeniem. W dolnej partii znajdował się krucyfiks ze srebrnymi figurami Matki Boskiej i św. Jana. W bocznych osiach ustawiono takież figury św. Kazimierza i św. Zygmunta. W drugiej kondygnacji umieszczono dwie kolejne srebrne figury, których mniszka nie określiła. Według niej w zwieńczeniu znajdowała się figura Maryi z dwoma aniołami.

Nienazwane przez s. Marię Magdalenę od Zbawiciela postacie drugiej kondygnacji to znane z innych opisów sanktuarium figury św. Piotra i św. Pawła ${ }^{29}$. Problematyczne jest

\footnotetext{
25 AKB 255, k. 83r-84v.

26 Kaplica św. Kazimierza ufundowana została przez Zygmunta III Wazę w 1623 r. Zasadnicze prace zakończono w 1636 r. Do końca lat czterdziestych XVII w. w jej wnętrzu wykonywano jednak uzupełniające prace dekoracyjne. Kaplica ta, być może najważniejsza inicjatywa artystyczna pierwszego Wazy na tronie polsko-litewskim, ma bardzo bogatą literaturę. Zestawiono ją w publikacjach: P.J. Jamski, Ottarz relikwiarzowy w wileńskiej Kaplicy św. Kazimierza w pierwszej połowie XVII wieku, „Barok”, 12/2005, nr 2, s. 41-44; idem, Kaplica świętego Kazimierza w Wilnie i jej twórcy, „Biuletyn Historii Sztuki”, 68/2006, nr 1, s. 19; B.R. Vitkauskienè, Karaliaus Zigmanto Vazos užsakymai Vilniaus Žemutineje pilyje, „Dailès Istorijos Studijos. Kultūros, Filosofijos ir Meno Institutas“, 2/2006, s. 46-48.

27 Kaplica Niepokalanego Poczęcia Najświętszej Maryi Panny, dawna królewska, nie cieszyła się dotychczas zainteresowaniem badaczy. Jej początki sięgają czasów Kazimierza Jagiellończyka, ale nowożytny kształt budowli nadał dopiero biskup Eustachy Wołowicz, który przeznaczył ją na swoje mauzoleum. Prace rozpoczęto najpewniej ok. 1625 r., a w zasadniczym kształcie ukończono do 1631 r. Historycy sztuki pomijają także działalność fundacyjną biskupa, nie tylko doskonale wykształconego, ale i odznaczającego się wyszukanym smakiem artystycznym. Eustachy Wołłowicz rozumiał także ogromną siłę kreacyjną tkwiącą w sztuce o czym świadczą medale oraz grafika powstała w jego kręgu. W. Zahorski, Katedra wileńska, Wilno 1904, s. 120-125; M. Janicki, Willa Eustachego Wołtowicza w Werkach pod Wilnem i jej epigraficzny program ideowy, „Barok”, 6/1997, nr 2, s. 123-149; M. Kałamajska-Saed, Litewska Pietà Michała Anioła, w: Mowa i moc obrazów. Prace dedykowane profesor Marii Poprzęckiej, Warszawa 2005, s. 55-58; P.J. Jamski, Kaplica świętego Kazimierza ..., op. cit., s. 21, 33; M. Jarczykowa, , Heretycki biskup” Eustachy Wołlowicz w kręgu Radziwiłłów birżańskich, „Wschodni Rocznik Humanistyczny”, 4/2007, s. 53-65.

28 Więcej na ten temat A.S. Czyż, op. cit., s. 73-81, 124-125.

29 Najważniejsze opisy kaplicy św. Kazimierza pozostawił w 1636 r. nieznany jezuita oraz jej proboszcz Mikołaj Zgierski, który w 1698 r. sporządził dokumentację pierwszego ołtarza na podstawie przekazów osób, które go
} 
natomiast zwieńczenie, w którym jezuita, autor opisu ołtarza z I636 r., w przeciwieństwie do zakonnicy, zobaczył „Christi triumphantis icon [...] et hinc inde duo angeli” ${ }^{\circ}$. Biorąc pod uwagę, że s. Maria Magdalena od Zbawiciela nie wymieniła płaskorzeźbionego srebrnego wizerunku Jerozolimy, na tle którego wisiał krucyfiks, oraz nie zauważyła gołębicy Ducha Świętego ${ }^{31}$, a figur z drugiej kondygnacji nie określiła, mogło tu dojść z jej strony do pomyłki związanej z elementami położonymi powyżej wzroku i do tego najpewniej na tle okna.

S. Maria Magdalena od Zbawiciela chwaląc kaplicę, jej przestrzenne i jasne wnętrze wraz z bogatą marmurową okładziną skonstatowała ,ale jeszcze z wierzchu [tj. u góry] niedokończona, jeszcze rosztowanie jest”. Owe rusztowanie, które umożliwiało prowadzenie prac dekoracyjnych powyżej gzymsu, być może w kopule, nie pozwoliło zakonnicom odpowiednio przyjrzeć się obrazom znajdującym się w górnej części ścian. Mniszka opisała je jako dosyć piękne. Niezwykle pozytywnie wypowiedziała się natomiast o malowidłach, które przedstawiały dzieje życia św. Kazimierza i św. Zygmunta. Obrazy, umieszczone we wnękach ścian bocznych niezasłoniętych rusztowaniem, zakonnica określiła jako wymalowane bardzo pięknie.

Do tej pory jest to w zasadzie jedyna wzmianka źródłowa o dekoracji malarskiej kaplicy św. Kazimierza i tematyki, którą w niej podjęto. Wpisywała się ona w dynastyczno-propagandowe treści kreowane w kaplicy, ale była także odpowiedzią na ówczesne zainteresowanie hagiografią i kultem świętych żyjących w odległych czasach. Wzmiankowaną i niezwykle pozytywnie ocenioną przez kronikarkę dekorację wykonał na przełomie I635 i I636 r. zatrudniony z inicjatywy Władysława IV Bartłomiej Strobel, który m.in. za tę udaną realizację otrzymał w I639 r. indygenat ${ }^{32}$.

W innym, niezwykle ważnym źródle dotyczącym kaplicy św. Kazimierza, w rozliczeniu wydanym Piotrowi Nonhardtowi przez kancelarię podskarbiego wielkiego litewskiego Stefana Paca w I63I r., podano informację o obrazach „,aniołów ośmiu większych” oraz o wizerunku ,zamku smoleńskiego"33. Trudno dowieść, czy wzmiankowane przez s. Marię Magdalenę od Zbawiciela słabsze i wiszące nieco wyżej obrazy to postacie aniołów z I63I r. Ze względu na rozmiar raczej nie przewidziano dla nich miejsca w ośmiu płycinach usytuowanych ponad niszami, gdzie w osiemnastym stuleciu stanęły drewniane i posrebrzane figury świętych monarchów. Być może w miejscu tym, lub w płycinach poniżej, planowano stworzyć galerię zwycięstw Jagiellonów i Wazów poprzez prezentację wizerunków zdobytych miast, co wpisywało się w dynastyczno-propagandowe treści kaplicy św. Kazimierza. Byłoby to tym bardziej pożądane, że przynajmniej część z owych wiktorii dokonano pod patronatem świętego królewicza ${ }^{34}$.

widziały. P.J. Jamski, Ottarz relikwiarzowy..., op. cit., s. 53-54; B.R. Vitkauskienė, Karaliaus Zigmanto ..., op. cit., s. 58-60; eadem, Zlotnictwo wileńskie. Ludzie i dzieła XV-XVIII wiek, Warszawa 2006, s. 191-192.

30 Cyt. za B. R.Vitkauskienè, Zlotnictwo..., op. cit., s. 192.

31 P.J. Jamski, Oltarz relikwiarzowy..., op. cit., s. 53-54.

32 J. Tylicki, Barttomiej Strobel. Malarz epoki wojny trzydziestoletniej, t. 1, Torun 2000, s. 84-86, 415-416; t. 2, s. 55. Kolejny malarz Giacinto Campana pracował w kaplicy od 1639 r. K. Mikocka, Nowe materialy dotyczace budowy i kaplicy św. Kazimierza w Wilnie, „Kwartalnik Architektury i Urbanistyki”, 26/1981, nr 3/4, s. 237, 239; P.J. Jamski, Kaplica świętego Kazimierza ..., op. cit., s. 35-36.

33 P.J. Jamski, Kaplica świętego Kazimierza ..., op. cit., s. 41 (tu publikacja źródła z archiwum Pacowskiego wraz z obszernym i ciekawym artykułem).

34 Były to bitwy pod Orszą (1514 r.) i Połockiem (1518 r.), pokonanie wojsk cara Wasyla III (1519 r.), zdobycie Smoleńska (1611 r.) i Chocimia (1624 r.). K. Moisan-Jabłońska, Obrazowanie walki dobra ze złem, Kraków 2002, 
Prestiżowy obchód katedry zakonnice zakończyły w kaplicy, gdzie pierwotnie znajdowało się ciało Jagiellona. Dawną kaplicę królewską, w I623 r. przekazaną biskupowi Eustachemu Wołłowiczowi w zamian za kaplicę biskupa Pawła Holszańskiego, mniszki nawiedziły na wyraźną prośbę Anny Marii Ancilli Pacowej. Zachęcone przez podkanclerzynę zmówiły za jej wuja paciorek, zapewne przy niewymienionym w dzienniku nagrobku biskupa, zmarłego W I630 r ${ }^{35}$ S. Maria Magdalena od Zbawiciela ponownie przekazała wrażenie przestrzenności i jasności wnętrza, nakrytego kopułą ${ }^{36}$. W ołtarzu zgodnie z wezwaniem kaplicy znajdował się obraz Matki Boskiej. Kronikarka odnotowała, że posadzka była wyłożona marmurem zapewne popularnym w tym czasie w Rzeczpospolitej kamieniem z Olandii. Obok kaplicy znajdowała się wygodna i piękna zakrystia.

Inicjatywa Paców, aby z całego Wilna i z samej katedry karmelitankom bosym oraz towarzyszącym im zakonnikom oraz gościom zjeżdżającym się na uroczystości wprowadzenia mniszek do klasztoru pokazać jedynie kaplice św. Kazimierza i Niepokalanego Poczęcia Najświętszej Maryi Panny, wskazuje, że nie przepuszczali żadnej okazji, aby stosownie zaprezentować siebie i własną rodzinę. Jednak przytoczony i zanalizowany opis z diariusza karmelitanek bosych sporządzony w I638 r. jest także, a może przede wszystkim, świadectwem ogromnej czci, jaką otaczano świętego królewicza oraz podziwu, który wzbudzało dedykowane mu sanktuarium ufundowane przez Zygmunta III.

Zacytowany po raz pierwszy w literaturze przedmiotu obszerny fragment z kroniki karmelitanek bosych przynosi także potwierdzenie i uzupełnienie kilku dotychczas brakujących informacji na temat wystroju wnętrza kaplicy św. Kazimierza przed najazdem moskiewskim W I654 r., kiedy zostało ono bardzo mocno zniszczone. Przede wszystkim należy podkreślić, że tak jak inne źródła s. Maria Magdalena od Zbawiciela potwierdziła, że prace dekoracyjne trwały w kaplicy jeszcze po I636 r., kiedy dokonano translacji ciała świętego. Wnęka na relikwiarz znajdująca się pod mensą ujęta była hebanowymi kolumnami, których trzony ozdabiały plakietki z kości. Przy tym był on przesłonięty kratą mosiężną, a nie srebrną. Obie te informacje uzupełniają udaną rekonstrukcję ołtarza autorstwa Piotra J. Jamskiego ${ }^{37}$.

Szczególnie ważne jest ustalenie tematyki malowideł wykonanych przez Bartłomieja Strobla i fakt ich umieszczenia na ścianach bocznych kaplicy. Wydaje się interesujące, że s. Maria Magdalena od Zbawiciela nie wymieniła ekskluzywnego - srebrnego wystroju i wyposażenia kaplicy, w tym ołtarzyków. Być może powstało ono po I638 r. ${ }^{38}$

Informacje o kaplicy Niepokalanego Poczęcia Najświętszej Maryi Panny są w przeciwieństwie do sanktuarium świętego królewicza bardzo skromne. Jednak chciałoby się, aby fakt opisania przez zakonnicę wnętrza niemal tymi samymi słowami co w przypadku kaplicy św. Kazimierza, zaprojektowanej najpewniej przez Konstantego Tencallę̧3, sugerował

\footnotetext{
s. 295-297; P.J. Jamski, Kaplica świętego Kazimierza ..., op. cit., s. 36.

35 W. Zahorski, op. cit., s. 124-125; M. Matušakaitè, Išejusiems atminti. Laidosena ir kapu ženklinimas LDK, Vilnius 2009, s. 181-183.

36 W. Zahorski, op. cit., s. 122-123.

37 P.J. Jamski, Ottarz relikwiarzowy..., op. cit., s. 53-54, 58.

38 P.J. Jamski, Kaplica świętego Kazimierza..., op. cit., s. 25, gdzie informacje, że srebrny wystrój, w tym dwa mniejsze ołtarzyki, powstawały sukcesywnie od ok. $1627 \mathrm{r}$.

39 Spory atrybucyjne zob. np. M. Morelowski, Zagadnienie twórcy kaplicy św. Kazimierza i kościoła św. Teresy w Wilnie a Constantino Tencalla projektodawca kolumny Zygmunta III w Warszawie, „Prace i materiały sprawozdawcze sekcji historii sztuki”, 2/1935, s. 302-303; M. Karpowicz, Matteo Castello. Architekt wczesnego baroku, Warszawa 1994, s. 73-78; H. Samsonowicz, Kaplica św. Kazimierza w Wilnie i uroczyste przeniesienie relikwii
} 
kompozycyjne podobieństwo, a być może i to samo autorstwo. Kwestia ta wymaga jednak dalszych badań i w tym momencie jest nadal otwarta.

\section{Chapels of St. Casimir and the Immaculate Conception at the Vilnius Cathedral as seen by Carmelite nuns - unrecognised source from 1638 Summary}

The article recalls a source from I638 which has hitherto not been referred to in the subject-matter literature, concerning the history of two chapels at the cathedral in Vilnius: the chapel of St. Casimir founded by King Zygmunt III, and the chapel of the Immaculate Conception which was furnished as a burial chapel by Bishop Eustachy Wołłowicz (lit. Eustachijus Valavičius). The source is a diary from travels from Lublin to Vilnius (I4 November 26 December I638) written by Carmelite nuns when going to a new monastery founded by Stefan Pac (lit. Steponas Pacas) and his wife Anna Maria Ancilia née Rudomina-Dusiacka (lit. Ona Marija Ancilia Rudomina-Dusiackaitè). The memoirs were written by a nun, Mary Magdalene (Anna Żaboklicka) who described various aspects of their journeys as well as a visit to the Vilnius Cathedral organised by the Pac family. The nuns were particularly impressed by the chapel of St. Casimir. Thanks to the fact that the nun described the chapel in detail, it was possible to reconstruct the subjects of some paintings by Bartłomiej Strobel, and to additionally interpret several facts connected with the appearance of the altar with the reliquary of St. Casimir. Even though the description of the chapel of Bishop Eustachy Wołłowicz is not as detailed, it should be underlined that by inviting the nuns there, the Pac family wanted to emphasise their kinship with the monarch of Vilnius, who was commonly highly regarded.

Keywords: Vilnius, chapel of St. Casimir, chapel of the Immaculate Conception, Pac family, Carmelite nuns

Nota o Autorze: Dr hab. Anna Sylwia Czyż. Historyk sztuki, zajmuje się okresem nowożytnym, ze szczególnym uwzględnieniem sztuki na terenie Wielkiego Księstwa Litewskiego, zagadnień formalnych i ideowych, fundacji artystycznych i treści propagandowych w szerokiej panoramie kulturowej i historycznej. Bierze udział w inwentaryzacji zabytków sztuki sakralnej i sepulkralnej - polskiego dziedzictwa na dawnych Kresach Wschodnich (Ukraina, Litwa) i w USA.

świętego w 1636 roku, w: Sztuka ziem wschodnich Rzeczypospolitej XVI-XVIII w., red. J. Lileyko, Lublin 2000, s. 335-336; P.J. Jamski, Kaplica świętego Kazimierza ..., op. cit, s. 19, 27-30. 